\title{
Ultrasound-guided foam sclerotherapy for severe chronic venous insufficiency
}

\section{Escleroterapia ecoguiada com espuma para tratamento da insuficiência venosa crônica grave}

Guilherme Camargo Gonçalves de-Abreu1; Otacílio de Camargo Júnior'; Márcia Fayad Marcondes de-Abreu1; José luís Braga DE-AQUINO, TCBC-SP'1.

\begin{abstract}
A B S T R A C T
Chronic venous insufficiency is characterized by cutaneous alterations caused by venous hypertension; in severe forms, it progresses to lower limb ulcers. Lower limb varicose veins are the main cause of chronic venous insufficiency, and the classic treatment includes surgery and compressive therapy. Minimally invasive alternative treatments for varicose veins include new techniques such as venous thermal ablation using laser or radiofrequency. The use of different methods depends on clinical and anatomical factors. Ultrasound-guided foam sclerotherapy is the venous injection of sclerosing foam controlled by Doppler ultrasound. Sclerotherapy is very useful to treat varicose veins, and probably, is cheaper than other methods. However, until the present, it is the less studied method.
\end{abstract}

Keywords: Varicose Ulcer. Varicose Veins. Venous Insufficiency. Sclerotherapy. Ultrasonography, Doppler, Duplex.

\section{INTRODUCTION}

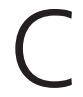
hronic venous insufficiency $(\mathrm{CVI})$ is characterized by cutaneous alterations caused by venous hypertension ${ }^{1-3}$. Lower limb varicose veins are the most frequent cause of $\mathrm{CVI}^{4}$ and the most severe form of the disease is venous ulcer $^{5}$. It is estimated that 30 to $40 \%$ of adult population presents varicose veins ${ }^{6,7}$ and up to $6 \%$ of patients with varicose veins will develop ulcers at some time in their lives ${ }^{8}$. Up to $30 \%$ of varicose veins can progress to more severe forms of $C V I^{9,10}$. CVI causes pain, functional impairment and worsening of quality of life $\mathrm{e}^{11-14}$. Almost $1 \%$ of general population may present venous ulcer in some moment and prevalence of open venous ulcer is around $0.1 \%$ to $0.3 \%{ }^{8,15}$. In Brazil, from 2009 to 2013, 420,000 hospitalizations were caused by varicose veins and it was spent more than U\$ 90 million $^{16}$. In the same period, more than 220,000 temporary social security assistant were granted, with an expense with venous disease of more than US\$ 60 million. From 2008 to 2012, there were 5,5 thousand retirements due to incapacity and lower limb varicose veins ${ }^{17}$.

\section{Importance of great saphenous vein (GSV)}

In a study of 3072 patients followed and examined for more than six years, varicose vein prevalence increased from $22.7 \%$ to $25.1 \%$ and prevalence of CVI from $14.5 \%$ to 16 . Among patients with GSV reflux, $31.8 \%$ showed worsening of $\mathrm{CVI}$ and only $19.8 \%$ of those without reflux progressed ${ }^{9,15}$. Reflux to great saphenous vein is the most frequent event associated to $\mathrm{CVI}$ and ulcer formation ${ }^{4,18}$. In the presence of venous reflux, a long liquid column is formed, increasing hydrostatic pressure and venous hypertension ${ }^{19}$. GSV reflux is identified in up to $80 \%$ of patients with $\mathrm{CVI}^{20-23}$.

\section{Chronic venous insufficiency evaluation}

Guidelines based on evidences recommend evaluation of patients with interview and physical exam, Doppler vascular ultrasound exam (DUS) and categorization of patients using CEAP classification ${ }^{1,4}$. CEAP classification describes systematically CVI according to clinical presentation, etiology (primary or secondary), anatomy (superficial, deep and perforating veins) and physiopathology (obstruction, reflux, or both). It guides treatment $^{24-26}$, but with low sensitivity to slight alterations

1 - Pontifical Catholic University of Campinas, Campinas, SP, Brazil. 
of the severity of the disease ${ }^{27}$. Follow-up of treatment results must include evaluation of quality of life, severity score and anatomic and physiologic data obtained by DUS. Clinical score of severity of disease proposed by the American Venous Forum is based on signals and symptoms identified by the examiner and allows follow-up of CVI evolution ${ }^{28}$. The score does not measure quality of life, but is sensitive to clinical presentation and is considered the best method nowadays to follow up the results of treatment $t^{4,29}$. Recently, it is becoming popular the evaluation of quality of life (QL) to quantify the impact of CVI on patients ${ }^{30}$. QL of patients with CVI is altered by physical aspect, pain, functional impairment and mobility deficit31,32. Specific questionnaires for $\mathrm{CVI}$ QL evaluation are validated in English and are difficult to use in other languages, since they must be translated and validated ${ }^{33-35}$. Charing Cross and Aberdeen question forms are translated and validated in Portuguese ${ }^{36,37}$. Evolution of disease is best assessed when multiple instruments are used, avoiding systematic errors of single question forms ${ }^{37-39}$. Anatomic and functional evaluation of venous system must be made by Doppler ultrasound (DUS), the ideal method, since is reproducible and non-invasive, allowing the access to venous patency or occlusion, identification and quantification of venous reflux, measure of caliber of veins and differentiation of primary and secondary venous disease ${ }^{40-42}$. DUS does not identify venous hypertension. Venous pressure measure is invasive and in the present is not often performed ${ }^{43}$.

\section{Treatment}

Clinical treatment is based in rest with elevation of lower limbs and use of compressive socks. Most patients may benefit of compressive treatment that is recommended to open or healed varicose ulcer and is not indicated to patients with arterial obstruction. Compressive treatment improves symptoms and is efficient for ulcer healing, but with low adherence. Clinical treatment does not eliminate varicose veins and does not alter anatomic basis of venous hypertension. Rate of recurrence of ulcer in one year reaches $70 \%$, and $35 \%$ of patients have four or more episodes of ulcer ${ }^{44,45}$. Obese and older patients have difficulty to wear elastic stockings, $15 \%$ are not capable to use them and $26 \%$ need help to wear them ${ }^{46,47}$. Low adherence to treatment is responsible for ulcer recurrence ${ }^{48}$. Single compressive therapy is not efficient for patients with varicose veins and $\mathrm{CV}{ }^{49-52}$.

In our country, the most common treatment for varicose veins and GSV reflux is surgical (proximal ligature and flebo-extraction of great saphenous vein) ${ }^{1,2,53}$. In patients with GSV reflux and intact deep venous system, surgery is efficient and indicated to avoid recurrence of varicose ulcer ${ }^{5,54}$. In the ESCHAR randomized study, surgery and clinical treatments were equivalent: $65 \%$ of ulcer healed in 24 weeks. Surgery was not able to heal ulcers more rapidly, but, after 12 months, recurrence was $28 \%$ in the group without surgery and $12 \%$ in the surgical group 55,56 . Surgery improves quality of life ${ }^{12}$, but cannot be performed in a considerable amount of patients. In randomized trials, up to $25 \%$ of patients refuses surgery ${ }^{45,56}$. Surgical patients present more pain and post-operatory discomfort and delay resuming work activities ${ }^{57}$. In five years, recurrence, with new indication of surgery, is $6 \%{ }^{58}$. Complications such as deep venous thrombosis (DVT) may occur in $5 \%$ of patients, saphenous nerve lesion in 7\% and hematoma in $33 \%{ }^{59}$. Worse surgical results are related to pre-operatory factors such as body mass index superior to $29 \mathrm{~kg} /$ $\mathrm{m}^{2}$, previous pregnancies, recurrent varicose veins, $\mathrm{CVI}$ with eczema and healed ulcers ${ }^{60-62}$.

Among minimally invasive techniques for the treatment of varicose veins and reflux of GSV it is included ultra-sound guided foam sclerotherapy (UFS) and thermal ablation using radiofrequency or laser. Thermal ablation is performed by inserting a thermal element catheter in the distal part of GSV by puncture. The procedure is performed with femoral blockage or with local anesthesia. Catheter must progress proximally inside the vein, in all extension to be treated. Thermal energy released by the catheter destroys venous endothelium. Veins with excess tortuosity, occluded segments, stenotic, or with parietal irregularities may impair progression of catheter. Big diameter veins are challenging for thermal ablation, since they distance thermal element from endothelium. Excessively superficial veins increase the risk of thermal lesion of skin. Finally, costs of catheters and generators limit their use. Minimally invasive treatments present advantages such as rapid recovery of patients and possibility of ambulatory treatment. These modali- 
ties have good relation cost/efficiency and complication rate similar to conventional surgical treatment. According to recommendations of the British National Institute for Health and Clinical Excellence, these treatments must by primarily used in relation to conventional surgery ${ }^{49}$. Patients with worse quality of life had better benefits when submitted to minimally invasive techniques, regardless the one used ${ }^{38,63}$. Ultrasound guided foam sclerotherapy is less expensive than other methods, but cost analysis in Brazil is lacking.

\section{History}

Elsholz (1623-1688) was the first to perform injection in humans and Zollikofer (1682) was the first to perform sclerotherapy ${ }^{64}$. Since XVII Century, several sclerosing agents were used, and many of them were toxic. Varicose veins sclerotherapy was used and favored until XIX Century. In the XX Century, surgical technique developed and became the treatment with better results; therefore, sclerotherapy for trunk veins was abandoned ${ }^{65}$. Also, during XX Century, many reports of the use of detergent sclerosing agents were published, with higher sclerosing power, forming foam when mixed with gas. In 1937, Biegeleisen used etanolamine; in 1946, Reiner used tetradecyl sodium sulfate and, in 1963, Henschel described sclerotherapy with polidocanol ${ }^{66}$. The first description of foam sclerotherapy was in 193967. In 1944, Orbach described the technique of blood displacement with air bubble to treat varicose veins with diameter of up to $4 \mathrm{~mm}$, and, in 1956, Fluckiger described that foam reached distant places from the point of injection by manual massage orientation ${ }^{67-69}$. In 1989, Knight $^{70}$ described the ultrasound-guided venous puncture and, in 1993, Schadeck ${ }^{71}$ described that foam was visible at ultrasound, allowing observation of its progress. In 1995, Cabrera ${ }^{72}$ described good results for ultrasound guided sclerotherapy using foam, that was patented for use in saphenous vein. In 2000, Tessari ${ }^{73}$ described the reproducible low cost technique to produce foam using syringes connected to three-way stopcock, mixing liquid and air at a 1:4 proportion, displacing the mix from one syringe to another at least for ten times. Tessari method produces an homogenous and stable foam that popularized foam sclerotherapy $68,72,73$.

\section{Foam sclerotherapy results}

In 2000, Cabrera et al. ${ }^{74}$ published a retrospective study of 500 patients with GSV reflux treated by UFS and reported occlusion of $81 \%$ of treated veins. They did not report any severe complication ${ }^{75}$. Wright et al. ${ }^{76}$, in 2006, treated 437 patients, $70.9 \%$ with GSV reflux. They reported elimination of reflux in $83.9 \%$ of treated veins with UFS in one year. Foam sclerotherapy was inferior to surgery to eliminate venous reflux, but patients returned to daily activities more rapidly. Rasmussen et al. ${ }^{77}$, in 2011, studied 580 limbs with GSV reflux, randomized for surgical treatment, thermal ablation or UFS. 1443 were submitted to foam sclerotherapy and, after one year of treatment, $16.3 \%$ maintained reflux, an index superior to other groups. Patients had faster recovery with less pain than those treated by surgery. There was no statistical difference among complications of studied groups ${ }^{77}$. Brittenden et al. ${ }^{78}$, in a randomized trial, compared foam, surgery and thermal ablation in 785 patients. 280 patients were submitted to foam sclerotherapy. In six months, $63 \%$ of veins eliminated reflux. UFS result was inferior to surgical and thermal ablation groups. Wright, Rasmussen and Brittenden studies, as well as most studies on foam sclerotherapy, are characterized by the small proportion of patients with open or healed ulcer ${ }^{76-78}$. Rate of occlusion of treated veins in several studies varied from 53 to $85 \%{ }^{75,78-83}$. Myers ${ }^{84}$ studied 1189 sclerotherapies in 489 patients; 454 GSV were treated and $53.1 \%$ of veins occluded after one single session of sclerotherapy. Occlusion rate of tributary veins was higher than of GSV. Veins with diameter higher than $6 \mathrm{~mm}$ had worse results than those with five or lower diameter. Best results were observed with foam sclerotherapy, with more than $12 \mathrm{ml}$ of volume and with sclerosing agents with higher concentration ${ }^{84}$.

Interest of foam sclerotherapy of varicose veins in patients with severe $\mathrm{CVI}$ is justified since frequently these patients are older and less prone to surgical treatment. Few randomized studies compared UFS to clinical treatment for ulcer healing and casuistic is small. There are evidences of favoring it in detriment to surgical treatment. In a meta-analysis Mauck ${ }^{85}$ identified less recurrence of varicose ulcers when venous reflux was 
surgically removed. Mauck results were similar to those of ESCHAR study. Several authors that study healing of varicose ulcers following UFS report healing rates higher than those of ESCHAR study, however, there is a predominance of non-comparative studies. O'Hare ${ }^{86}$ reported $91.2 \%$ rate of healing in 24 weeks, Kulkarni ${ }^{87} 71.1 \%$ in 24 weeks, Campos $^{88} 91.3 \%$ after one year and Cabrera ${ }^{89}$ $83 \%$ in six months. Campos ${ }^{90}$, in 2014, randomized 49 patients with ulcer and GSV reflux for surgery or UFS. Twenty three limbs were submitted to UFS and healing occurred in $91.3 \%$ after one year of treatment. There were no severe complications or differences in relation to surgical group. Ulcer healing rate, clinical improvement and of QL were similar ${ }^{88,90}$. Silva ${ }^{91}$ identified healing of $84.2 \%$ of ulcers. Randomized studies report similar healing of ulcers with surgery, thermal ablation or UFS, with numerous casuistic ${ }^{77,92,93}$. Brittenden ${ }^{94}$ showed improvement of QL, however, less intense in patients treated by UFS when compared to surgery.

\section{Safety}

Wright ${ }^{76}$ reported an incidence of deep venous thrombosis (DVT) in 5.3\% of patients after injection of $60 \mathrm{ml}$ of foam, and the author decided to reduce maximum volume to $30 \mathrm{ml}$. After reduction, 95 patients were treated without new episodes of DVT ${ }^{76}$. According to European consensus, foam volume should be limited to $10 \mathrm{ml}$ per session ${ }^{95,96}$. Yamaki ${ }^{97}$ affirms that equivalent volumes injected fractioned caused less progression of foam to deep venous system evaluated by Doppler. When foam volume used is reduced, the procedure is safer, but requires a higher number of treatment sessions to eliminate numerous and bulky varicose veins. Some authors use the maneuver of elevation the limb to reduce venous volume and allow contact of lesser volume with endothelium ${ }^{96,97}$.

More frequent side effects following UFS are phlebitis and cutaneous pigmentation. There are a few reports of severe complications such as DVT, pulmonary thromboembolism, stroke and cerebral embolization in patients with permeate oval foramen. Severe complications are rare $(<0.1 \%)^{82,98}$. Thomasset ${ }^{99}$ states that women have more side effect reactions than men, specifically cutaneous pigmentation. Cavezzi and Par$\mathrm{si}^{100}$ estimates the occurrence of pigmentation in $10 \%$ to $30 \%$ of patients, with resolution in 12 months. Jia ${ }^{82}$ in a systematic review of more than 9000 sclerotherapies describes the most frequent complications: $4.7 \%$ of phlebitis, $17.8 \%$ of cutaneous pigmentation and $25.6 \%$ of local pain. He also observed less than $1 \%$ of deep venous thrombosis and pulmonary embolism, and $1.4 \%$ of visual disturbances.

\section{Current Recommendations}

Laser or radiofrequency ablation is recommended by guidelines of "American Venus Forum" (AVF) and British National Institute for Health and Clinical Excellence (NICE) as first choice of treatment of saphenous veins with reflux. There are evidences that treatment avoids ulcer recurrence and speeds recovery with less pain than conventional surgery. AVF states that evidences on UFS are insufficient ${ }^{4,5}$. According to NICE, evidences on safety and efficacy of UFS are adequate and recommends that foam sclerotherapy must be offered primarily than surgical treatment ${ }^{49}$. European guidelines published in 2014 considered UFS evidences adequate and recommend the method to treat saphenous veins and varicose collateral veins ${ }^{96}$.

Patients submitted to UFS present better QL than surgical patients after four weeks of treatment due to less pain. After one year of treatment, surgical patients show better QL, but with higher rate of recurrence of varicose veins than those submitted to UDS ${ }^{77,101}$. UFS has lower cost and the procedure is faster, without the need of anesthesia ${ }^{88,102}$. It is reported higher recurrence rate of varicose veins and lower occlusion rate of treated veins with UDS, when compared to thermal ablation and surgical treatment. However, meta-analysis have identified similar efficacy of minimally invasive methods and surgical treatment ${ }^{83,103}$. According to guidelines of Brazilian Society of Vascular Surgery, UDS may be used as an alternative to surgery in patients with primary CVI1.

\section{Critical Opinion}

$\mathrm{CVI}$ is prevalent and causes important economic and social burden. Most studies primarily access patients with less severe disease and, rarely, results are categorized according to clinical class. Patients with severe $\mathrm{CVI}$ are usually older and less prone to surgical procedure. Sclerotherapy may replace surgical treatment 
of varicose veins in many patients. Main limitations of method include cutaneous pigmentation (frequent and usually compromise esthetical result), and the need of repeat treatment until total elimination of varicose veins. Patients must be warranted that esthetical result of foam sclerotherapy is less predictable than surgical resection. Low efficacy of a single session of sclerotherapy may be solved by subsequent sessions. Those enhance costs, but have no additional technical difficulty. After surgery of varicose veins, in case of necessity of reoperation, the presence of scars and adhesions may difficult technically the procedure or cause iatrogenic lesions. The main interests of UFS are its low cost, the easy application and low limitation in relation to other therapeutic methods. In literature, most studies show reduced evidence due to bias of selection and randomization ${ }^{49}$ and long term results are still lacking and must be checked by controlled randomized trials.

\title{
R E S U M O
}

\begin{abstract}
A insuficiência venosa crônica é caracterizada por alterações cutâneas decorrentes da hipertensão venosa que, nas formas graves, evoluem com úlceras nos membros inferiores. As varizes dos membros inferiores são a causa mais frequente de insuficiência venosa crônica, que tem como tratamentos clássicos a cirurgia de varizes e a terapia compressiva. Novas técnicas de termo-ablação venosa por laser e radiofrequência são alternativas minimamente invasivas para o tratamento de varizes. A aplicabilidade dos diferentes métodos é limitada por requisitos anatômicos e clínicos. A escleroterapia ecoguiada com espuma consiste na injeção endovenosa da espuma esclerosante monitorada pelo Ultrassom Doppler. A escleroterapia tem grande aplicabilidade para tratamento das varizes e, provavelmente, é mais barato que outros métodos. Entretanto é, até o momento, o método menos estudado.
\end{abstract}

Descritores: Varizes. Insuficiência Venosa. Úlcera da Perna. Escleroterapia. Ultrassom.

\section{REFERENCES}

1. Castro e Silva M, Cabral ALS, Barros Jr N, Castro AA, Santos MERC. Diretrizes sobre Diagnóstico, Prevenção e Tratamento da SBACV. Diagnóstico e tratamento da doença venosa. J Vasc Bras. 2005;4(3 Suppl 2): S185-94.

2. de Aguiar ET, Pinto L, Figueiredo MA, Savino Neto S. Diretrizes sobre Diagnóstico, Prevenção e Tratamento da SBACV. Úlcera de insuficiência venosa crônica. J Vasc Bras. 2005; 4(3 Supl 2):S195200.

3. Luccas GC, Menezes FH, Barel EV, Medeiros CAF. Varizes dos membros inferiores. In: Brito JC, editor. Cirurgia vascular e endovascular. 2nd ed. Revinter; 2002. p. 1509-26.

4. Gloviczki P, Comerota AJ, Dalsing MC, Eklof BG, Gillespie DL, Gloviczki ML, Lohr JM, McLafferty RB, Meissner MH, Murad MH, Padberg FT, Pappas PJ, Passman MA, Raffetto JD, Vasquez MA, Wakefield TW; Society for Vascular Surgery; American Venous Forum. The care of patients with varicose veins and associated chronic venous diseases: clinical practice guidelines of the Society for Vascular Surgery and the American Venous Forum J Vasc Surg. 2011;53:(5
Suppl):2S-48S.

5. O'Donnell TF, Passman MA, Marston WA, Ennis WJ, Dalsing M, Kistner RL, Lurie F, Henke PK, Gloviczki ML, Eklöf BG, Stoughton J, Raju S, Shortell CK, Raffetto JD, Partsch H, Pounds LC, Cummings ME, Gillespie DL, McLafferty RB, Murad MH, Wakefield TW, Gloviczki P; Society for Vascular Surgery; American Venous Forum. Management of venous leg ulcers: clinical practice guidelines of the Society for Vascular Surgery ${ }^{\circledR}$ and the American Venous Forum. J Vasc Surg. 2014;60(2 Suppl):3S-59S.

6. Scott TE, LaMorte WW, Gorin DR, Menzoian JO. Risk factors for chronic venous insufficiency: a dual casecontrol study. J Vasc Surg. 1995;22(5):622-8.

7. Evans CJ, Fowkes FG, Ruckley CV, Lee AJ. Prevalence of varicose veins and chronic venous insufficiency in men and women in the general population: Edinburgh Vein Study. J Epidemiol Community Health. 1999;53(3):149-53.

8. Nelzen O. Prevalence of venous leg ulcer: the importance of the data collection method. Phlebolymphology. 2008;15(4):143-150.

9. Rabe E. Epidemiology of varicose veins. Phlebolymphology. 2010;17(1):21.

10. Tatsioni A, Balk E, O'Donnell T, Lau J. Usual care in 
the management of chronic wounds: a review of the recent literature. J Am Coll Surg. 2007;205(4):617624e57.

11. Garratt AM, Macdonald LM, Ruta DA, Russell IT, Buckingham JK, Krukowski ZH. Towards measurement of outcome for patients with varicose veins. Qual Health Care. 1993;2(1):5-10.

12. Garratt AM, Ruta DA, Abdalla MI, Russell IT. Responsiveness of the SF-36 and a condition-specific measure of health for patients with varicose veins. Qual Life Res. 1996;5(2):223-34.

13. Lopes $C R$, Figueiredo $M$, Ávila AM, Soares LMBM, Dionísio VC. Avaliação das limitações de úlcera venosa em membros inferiores. J Vasc Bras. 2013;12(1):5-9.

14. Vlajinac HD, Radak DJ, Marinkovic JM, Maksimovic MZ. Risk factors for chronic venous disease. Phlebology. 2012;27(8):416-22.

15. Pannier F, Rabe E. Progression of chronic venous disorders: results from the Bonn Vein Study. J Vasc Surg. 2011;53(1):254-55.

16. Brasil. Ministério da Saúde. DATASUS [Internet]. [acesso 2016 Ago 29]. Disponível em: http://datasus. saude.gov.br/informacoes-de-saude/tabnet

17. Brasil. Ministério da Previdência Social. DATAPREV [Internet]. [acesso em 2016 Ago 19]. Disponível em: http://portal.dataprev.gov.br/

18. Pang AS. Location of valves and competence of the great saphenous vein above the knee. Ann Acad Med Singapore. 1991;20(2):248-50.

19. Bradbury A, Ruckley CV. Clinical presentation and assessment of patients with venous disease. In: Gloviczki P, editor. Handbook of venous disorders: guidelines of the American Venous Forum. 3rd ed. London: Hodder Arnold; 2009. p. 331-41.

20. Kistner RL, Eklof B, Masuda EM. Diagnosis of chronic venous disease of the lower extremities: the "CEAP" classification. Mayo Clin Proc. 1996;71(4):338-45.

21. 21. Hanrahan $L M$, Araki $C T$, Rodriguez $A A$, Kechejian GJ, LaMorte WW, Menzoian JO. Distribution of valvular incompetence in patients with venous stasis ulceration. J Vasc Surg. 1991;13(6):805-11.

22. Labropoulos N, Leon M, Geroulakos G, Volteas $N$, Chan P, Nicolaides AN. Venous hemodynamic abnormalities in patient with leg ulceration. Am J Surg. 1995; 169(6):572-4.
23. Obermayer A, Garzonk. Identifying the source of superficial reflux in venuos leg ulcers usin duplex ultrasound. J Vasc Surg. 2010;52(5):1255-61.

24. Leal JAR. Como avaliar o impacto da doença venosa crônica na qualidade de vida [dissertação]. Porto: Universidade do Porto; 2010.

25. Eklöf $B$, Rutherford RB, Bergan JJ, Carpentier PH, Gloviczki P, Kistner RL, Meissner MH, Moneta GL, Myers K, Padberg FT, Perrin M, Ruckley CV, Smith PC, Wakefield TW; American Venous Forum International Ad Hoc Committee for Revision of the CEAP Classification. Revision of the CEAP classification for chronic venous disorders: consensus statement. J Vasc Surg. 2004;40(6):1248-52.

26. Porter JM, Moneta GL. Reporting standards in venous disease: an update. International Consensus Committee on Chronic Venous Disease. J Vasc Surg. 1995;21(4):635-45.

27. Beebe HG, Bergan JJ, Bergqvist D, Eklof B, Eriksson I, Goldman MP, et al. Classification and grading of chronic venous disease in the lower limbs-a consensus statement. Organized by Straub Foundation with the cooperation of the American Venous Forum at the 6th annual meeting, February 22-25, 1994, Maui, Hawaii. Vasa. 1995;24(4):313-8.

28. Rutherford RB, Padberg FT Jr, Comerota AJ, Kistner RL, Meissner MH, Moneta GL. Venous severity scoring: an adjunct to venous outcome assessment. J Vasc Surg. 2000;31(6):1307-12.

29. Vasquez MA, Rabe E, McLafferty RB, Shortell CK, Marston WA, Gillespie D, Meissner MH, Rutherford RB; American Venous Forum Ad Hoc Outcomes Working Group. Revision of the venous clinical severity score: venous outcomes consensus statement: special communication of the American Venous Forum Ad Hoc Outcomes Working Group. J Vasc Surg. 2010;52(5):1387-96.

30. Murray CJ, Salomon JA, Mathers CD, Lopez AD. Summary measures of population health: conclusions and recommendations. In: Murray CJ, Salomon JA, Mathers CD, Lopez AD, editors. Summary Measures of Population Health: Concepts, Ethics, Measurement and Applications. Geneva, Switzerland: World Health Organization; 2002. p. 731-56.

31. van Kolaar I, Vossen C, Rosendaal F, Cameron L, 
Bovill E, Kaptein A. Quality of life in venous disease. Thromb Haemost. 2003;90(1):27-35.

32. Vasquez MA, Munschauer CE. Venous Clinical Severity Score and quality-of-life assessment tools: application to vein practice. Phlebology. 2008;23(6):259-75.

33. McDaniel MD, Nehler MR, Santilli SM, Hiatt WR, Regensteiner JG, Goldstone J, et al. Extended outcome assessment in the care of vascular diseases: revising the paradigm for the 21st century. Ad Hoc Committee to Study Outcomes Assessment, Society for Vascular Surgery/International Society for Cardiovascular Surgery, North American Chapter. J Vasc Surg. 2000;32(6):1239-50.

34. Leal FJ, Couto RC, Pitta GBB, Leite PTF, Costa LM, Higino WJF, et al. Tradução e adaptação cultural do Questionário Aberdeen para Veias Varicosas. J Vasc Bras. 2012;11(1):34-42.

35. Leal FJ, Couto RC, Pitta GBB. Validação no Brasil de Questionário de Qualidade de Vida na Doença Venosa Crônica (Questionário Aberdeen para Veias Varicosas no Brasil/AVVQ-Brasil). J Vasc Bras. 2015;14(3):241-7.

36. Couto RC, Leal FJ, Pitta GBB, Bezerra RC B, Segundo Walmir SS, Porto TM. Tradução e adaptação cultural do Charing Cross Venous Ulcer Questionnaire Brasil. J Vasc Bras. 2012;11(2):102-7.

37. Couto RC, Leal FJ, Pitta GBB. Validação do questionário de qualidade de vida na úlcera venosa crônica em língua portuguesa (Charing Cross Venous Ulcer Questionnaire - CCVUQ-Brasil). J Vasc Bras. 2016;15(1):4-10.

38. Lattimer CR, Kalodiki E, Azzam M, Geroulakos G. The Aberdeen varicose vein questionnaire may be the preferred method of rationing patients for varicose vein surgery. Angiology. 2014;65(3):205-9.

39. Staniszewska A, Tambyraja A, Afolabi E, Bachoo $P$, Brittenden J. The Aberdeen varicose vein questionnaire, patient factors and referral for treatment. Eur J Vasc Endovasc Surg. 2013;46(6):715-8.

40. Nicolaides AN; Cardiovascular Disease Educational and Research Trust; European Society of Vascular Surgery; The International Angiology Scientific Activity Congress Organization; International Union of Angiology; Union Internationale de Phlebologie at the Abbaye des Vaux de Cernay. Investigation of chronic venous insufficiency: a consensus statement (France, March 5-9, 1997). Circulation. 2000;102(20):E126-63.

41. Coleridge-Smith $P$, Labropoulos N, Partsch H, Myers K, Nicolaides A, Cavezzi A. Duplex ultrasound investigation of the veins in chronic venous disease of the lower limbs--UIP consensus document. Part I. Basic principles. Eur J VascEndovasc Surg. 2006 Jan;31(1):83-92.

42. Neumann $M$, Cornu-Thénard $A$, Jünger $M$, Mosti G, Munte K, Partsch H, et al. Evidence based (S3) Guideline for Diagnostics and Treatment of Venous Leg Ulcers. In: EDF guidelines leg ulcers / version 4.0. [cited 2016. Jul 07]. Available from: http:// www.euroderm.org/edf/index.php/edf-guidelines/ category/5-guidelines-miscellaneous?download=22: guideline-diagnostics-and-treatment-of-venous-legulcers-update-2014

43. Nicolaides AN, Miles C. Photoplethysmography in the assessment of venous insufficiency. J Vasc Surg. 1987;5(3):405-12.

44. Callam MJ, Harper DR, Dale JJ, Ruckley CV. Chronic ulcer of the leg: clinical history. Br Med J (Clin Res Ed). 1987;294(6584):1389-91.

45. Samuel N, Carradice D, Wallace T, Smith GE, Chetter IC. Endovenous thermal ablation for healing venous ulcers and preventing recurrence. Cochrane Database Syst Rev. 2013;(10):CD009494.

46. Reich-Schupke S, Murmann F, Altmeyer P, Stücker M. Compression therapy in elderly and overweight patients. Vasa. 2012;41(2):125-31.

47. Franks PJ, Oldroyd MI, Dickson D, Sharp EJ, Moffatt CJ. Risk factors for leg ulcer recurrence: a randomized trial of two types of compression stocking. Age Ageing. 1995;24(6):490-4.

48. Harper D, Nelson E, Gibson B, Prescott R, Ruckley CV. A prospective randomised trial of class 2 and class 3 elastic compression in the prevention of venous ulceration. Phlebology. 1995;(Suppl 1):872-3.

49. National Clinical Guideline Centre (UK). Varicose veins in the legs. The diagnosis and management of varicose veins. London (UK): National Institute for Health and Care Excellence; 2013. 
50. RajuS, Hollis K, Neglen P. Use of compression stockings in chronic venous disease: patient compliance and efficacy. Ann Vasc Surg. 2007;21(6):790-5.

51. Pannier F, Hoffmann B, Stang A, Jöckel KH, Rabe E. Prevalence and acceptance of therapy with medical compression stockings: results of the Bonn vein study. Phlebologie. 2007;36(5):245-9.

52. Mayberry JC, Moneta GL, Taylor LM Jr, Porter JM. Fifteen-year results of ambulatory compression therapy for chronic venous ulcers. Surgery. 1991;109(5):575-81.

53. Coleridge-Smith PD. Leg ulcer treatment. J Vasc Surg. 2009;49(3):804-8.

54. Lurie F, Creton D, Eklof B, Kabnick LS, Kistner RL, Pichot $\mathrm{O}$, et al. Prospective randomized study of endovenous radiofrequency obliteration (closure procedure) versus ligation and stripping in a selected patient population (EVOLVeS Study). J Vasc Surg. 2003;38(2):207-14.

55. Barwell JR, Davies CE, Deacon J, Harvey K, Minor $J$, Sassano A, et al. Comparison of surgery and compression with compression alone in chronic venous ulceration (ESCHAR study): randomised controlled trial. Lancet. 2004;363(9424):1854-9.

56. Gohel MS, Barwell JR, Taylor M, Chant T, Foy C, Earnshaw JJ, et al. Long term results of compression therapy alone versus compression plus surgery in chronic venous ulceration (ESCHAR): randomised controlled trial. BMJ. 2007;335(7610):83.

57. Nesbitt C, Eifell RK, Coyne P, Badri H, Bhattacharya V, Stansby G. Endovenous ablation (radiofrequency and laser) and foam sclerotherapy versus conventional surgery for great saphenous vein varices. Cochrane Database Syst Rev. 2011;(10):CD005624.

58. Dwerryhouse S, Davies B, Harradine K, Earnshaw JJ. Stripping the long saphenous vein reduces the rate of reoperation for recurrent varicose veins: fiveyear results of a randomized trial. J Vasc Surg. 1999 Apr;29(4):589-92.

59. van Rij AM, Chai J, Hill GB, Christie RA. Incidence of deep vein thrombosis after varicose vein surgery. $\mathrm{Br} J$ Surg. 2004;91(12):1582-5.

60. Fischer R, Chandler JG, Stenger D, Puhan MA, De Maeseneer MG, Schimmelpfennig L. Patient characteristics and physician-determined variables affecting saphenofemoral reflux recurrence after ligation and stripping of the great saphenous vein. J Vasc Surg. 2006;43(1):81-7.

61. Mackenzie RK, Lee AJ, Paisley A, Burns P, Allan PL, Ruckley $\mathrm{CV}$ et al. Patient, operative, and surgeon factors that influence the effect of superficial venous surgery on disease-specific quality of life. J Vasc Surg. 2002;36(5):896-902.

62. Islamoglu F. A alternative treatment for varicose veins: ligation plus foam sclerotherapy. Dermatol Surg. 2011;37(4):470-9.

63. Ghauri AS, Nyamekye I, Grabs AJ, Farndon JR, Whyman MR, Poskitt KR. Influence of a specialised leg ulcer service and venous surgery on the outcome of venous leg ulcers. Eur J Vasc Endovasc Surg. 1998;16(3):238-44.

64. Goldman MP. Sclerotherapy: treatment of varicose and telangiectatic leg vein. 2nd ed. Mosby-Year Book: St Louis; 1995.

65. Coppleson VM. The treatment of varicose veins by injection. 2nd ed. Sydney : Cornstalk Publ. Co.; 1929.

66. Bergan JJ. Foam sclerotherapy: a textbook. London: Royal Society of Medicine Press; 2008.

67. Wollmann JC. The history of sclerosing foams. Dermatol Surg. 2004;30(5):694-703. Erratum in: Dermatol Surg. 2005;31(2):249.

68. Geroulakos G. Foam sclerotherapy for the management of varicose veins: a critical reappraisal. Phlebolymfology. 2006;13(4):202-6.

69. vanCleef JF. [The history of endovenous techniques for treating varices]. Phlebologie. 2013;66(2):15-27. French.

70. Knight RM, Vin F, Zygmunt JA. Ultrasonic guidance of injection into the superficial venous system. In: Davy A. Stemmer R, editors. Phelobologie 89. Paris: John Libbey Eurotext; 1989. p. 339-41.

71. Schadeck M, Allaert FA. Duplex scanning in the mechanism of the scleroterapy: importance of the spasm. Phlebologie. 1995;Suppl 1:574-6.

72. Cabrera J, Cabrera J Jr, García-Olmedo MA. Nuevo método de esclerosis em las varices tronculares. Patol Vasc. 1995;4:55-73.

73. Tessari L, Cavezzi A, Frullini A. Preliminary experience with a new sclerosing foam in the treatment of 
varicose veins. Dermatol Surg. 2001;27(1):58-60.

74. Cabrera J, Cabrera J Jr, García-Olmedo MA. Treatment of varicose long saphenous veins with sclerosant in microfoam form: long-term outcomes. Phlebology. 2000;15(1):19-23.

75. Cabrera J, Cabrera J Jr, García-Olmedo MA. Sclerosants in microfoam. A new approach in angiology. Int Angiol. 2001;20(4):322-9.

76. Wright D, Gobin JP, Bradbury AW, Coleridge-Smith P, Spoelstra H, Berridge D, Wittens CHA, Sommer A, Nelzen O, Chanter D; The Varisolve $\AA$ European Phase III Investigators Group. Varisolve ${ }^{\circledR}$ polidocanol microfoam compared with surgery or sclerotherapy in the management of varicose veins in the presence of trunk vein incompetence: European randomized controlled trial. Phlebology. 2006;21(4):180-90.

77. Rasmussen $L H$, Lawaetz $M$, Bjoern $L$, Vennits B, Blemings A, Eklof B. Randomized clinical trial comparing endovenous laser ablation, radiofrequency ablation, foam sclerotherapy and surgical stripping for great saphenous varicose veins. Br J Surg. 2011;98(8):1079-87.

78. Brittenden J, Cotton SC, Elders A, Tassie E, Scotland $G$, Ramsay $C R$, et al. Clinical effectiveness and costeffectiveness of foam sclerotherapy, endovenous laser ablation and surgery for varicose veins: results from the Comparison of LAser, Surgery and foam Sclerotherapy (CLASS) randomised controlled trial. Health Technol Assess. 2015;19(27):1-342.

79. Rabe E, Otto J, Schliephake D, Pannier F. Efficacy and safety of great saphenous vein sclerotherapy using standardized polidocanol foam (ESAF): a randomised controlled multicentre clinical trial. Eur J Vasc Endovasc Surg. 2008;35(2):238-45.

80. Yamaki T, Nozaki M, Iwasaka S. Comparative study of duplex-guided foam sclerotherapy and duplexguided liquid sclerotherapy for the treatment of superficial venous insufficiency. Dermatol Surg. 2004;30(5):718-22; discussion 722.

81. Figueiredo $M$, Araújo SP, Penha-Silva $N$. Ecoescleroterapia com microespuma em varizes tronculares primárias. J Vasc Bras. 2006;5(3):177-83.

82. Jia X, Mowatt G, Burr JM, Cassar K, Cook J, Fraser $C$. Systematic review of foam sclerotherapy for varicose veins. Br J Surg. 2007;94(8):925-36.
83. van den Bos $R$, Arends $L$, Kockaert $M$, Neumann $M$, Nijsten T. Endovenous therapies of lower extremity varicosities: a meta-analysis. J Vasc Surg. 2009;49(1):230-9.

84. Myers KA, Jolley D, Clough A, Kirwan J. Outcome of ultrasound-guided sclerotherapy for varicose veins: medium-term results assessed by ultrasound surveillance. Eur J Vasc Endovasc Surg. 2007;33(1):116-21

85. Mauck KF, Asi N, Elraiyah TA, Undavalli C, Nabhan $\mathrm{M}$, Altayar $\mathrm{O}$, et al. Comparative systematic review and meta-analysis of compression modalities for the promotion of venous ulcer healing and reducing ulcer recurrence. J Vasc Surg. 2014;60(2 Suppl):73S92S.

86. O'Hare JL, Earnshaw JJ. Randomised clinical trial of foam sclerotherapy for patients with a venous leg ulcer. Eur J Vasc Endovasc Surg. 2010;39(4):495-9.

87. Kulkarni SR, Slim FJ, Emerson LG, Davies C, Bulbulia RA, Whyman MR, et al. Effect of foam sclerotherapy on healing and long-term recurrence in chronic venous leg ulcers. Phlebology. 2013;28(3):140-6.

88. Campos W Jr, Torres IO, da Silva ES, Casella IB, Puech-Leão P. A prospective randomized study comparing polidocanol foam sclerotherapy with surgical treatment of patients with primary chronic venous insufficiency and ulcer. Ann Vasc Surg. 2015;29(6):1128-35.

89. Cabrera J, Redondo P, Becerra A, Garrido C, Cabrera J Jr, García-Olmedo MA, et al. Ultrasoundguided injection of polidocanol microfoam in the management of venous leg ulcers. Arch Dermatol. 2004;140(6):667-73

90. Campos W Jr. Estudo comparativo entre escleroterapia com espuma de polidocanol e cirurgia convencional para tratamento de varizes primárias dos membros inferiores em portadores de úlcera venosa [dissertação]. 2014. São Paulo (SP): Universidade de São Paulo; 2014.

91. Silva MAM, Burihan MC, Barros OC, Nasser F, Ingrund JC, Neser A. Resultados do tratamento da Insuficiência Venosa Crônica grave com espuma de polidocanol guiada por ultrassom. J Vasc Bras. 2012;11(3):207-11.

92. Biemans AA, Kockaert M, Akkersdijk GP, van den Bos 
RR, de Maeseneer MG, Cuypers P, et al. Comparing endovenous laser ablation, foam sclerotherapy, and conventional surgery for great saphenous varicose veins. J Vasc Surg. 2013;58(3):727-34.

93. Shadid N, Ceulen R, Nelemans P, Dirksen C, Veraart J, Schurink GW, et al. Randomized clinical trial of ultrasound-guided foam sclerotherapy versus surgery for the incompetent great saphenous vein. Br J Surg. 2012;99(8):1062-70.

94. Brittenden J, Cotton SC, Elders A, Ramsay CR, Norrie J, Burr J, et al. A randomized trial comparing treatments for varicose veins. $N$ Engl J Med. 2014;371(13):1218-27.

95. Breu FX, Guggenbichler S. European Consensus Meeting on Foam Sclerotherapy, April, 4-6, 2003, Tegernsee, Germany. Dermatol Surg. 2004;30(5):709-17; discussion 717.

96. Rabe E, Breu FX, Cavezzi A, Coleridge Smith P, Frullini A, Gillet JL, Guex JJ, Hamel-Desnos C, Kern P, Partsch B, Ramelet AA, Tessari L, Pannier F; Guideline Group. European guidelines for sclerotherapy in chronic venous disorders. Phlebology. 2014;29(6):338-54.

97. Yamaki T, Nozaki M, Sakurai H, Takeuchi M, Soejima $\mathrm{K}$, Kono T. Multiple small-dose injections can reduce the passage of sclerosant foam into deep veins during foam sclerotherapy for varicose veins. Eur Vasc Endovasc Surg. 2009;37(3):343-8.

98. Guex JJ. Complications and side-effects of foam sclerotherapy. Phlebology. 2009;24(6):270-4.

99. Thomasset SC, Butt Z, Liptrot S, Fairbrother BJ, Makhdoomi KR. Ultrasound guided foam sclerotherapy: Factors associated with outcomes and complications. Eur J Vasc Endovasc Surg.
2010;40(3):389-92.

100. Cavezzi A, Parsi K. Complications of foam sclerotherapy. Phlebology. 2012;27 Suppl 1:46-51.

101. Figueiredo M, Araújo S, Barros N Jr, Miranda F Jr. Results of surgical treatment compared with ultrasound-guided foam sclerotherapy in patients with varicose veins: a prospective randomised study. Eur J Vasc Endovasc Surg. 2009; 38(6):758-76.

102. Bountouroglou DG, Azzam M, Kakkos SK, Pathmarajah M, Young P, Geroulakos G. Ultrasoundguided foam sclerotherapy combined with saphenofemoral ligation compared to surgical treatment of varicose veins: early results of a randomized controlled trial. Eur J Vasc Endovasc Surg. 2006;31(1):93-100.

103. Luebke T, Brunkwall J. Systematic review and metaanalysis of endovenous radiofrequency obliteration, endovenous laser therapy, and foam sclerotherapy for primary varicosis .J Cardiovasc Surg (Torino). 2008;49(2):213-33.

Received in: 02/03/2017

Accepted for publication: 22/06/2017

Conflict of interest: none.

Source of funding: none.

\section{Mailing address:}

Guilherme Camargo Gonçalves de Abreu

E-mail: gcgabreu@gmail.com / guilherme.cga@puccampinas.edu.br 